\title{
Regional variability of acidification in the Arctic: a sea of contrasts
}

\author{
E. E. Popova, A. Yool, Y. Aksenov, A. C. Coward, and T. R. Anderson \\ National Oceanography Centre, University of Southampton Waterfront Campus, European Way, Southampton SO14 3ZH, UK \\ Correspondence to: E. E. Popova (ekp@noc.ac.uk)
}

Received: 29 January 2013 - Published in Biogeosciences Discuss.: 18 February 2013

Revised: 6 December 2013 - Accepted: 9 December 2013 - Published: 23 January 2014

\begin{abstract}
The Arctic Ocean is a region that is particularly vulnerable to the impact of ocean acidification driven by rising atmospheric $\mathrm{CO}_{2}$, with potentially negative consequences for calcifying organisms such as coccolithophorids and foraminiferans. In this study, we use an ocean-only general circulation model, with embedded biogeochemistry and a comprehensive description of the ocean carbon cycle, to study the response of $\mathrm{pH}$ and saturation states of calcite and aragonite to rising atmospheric $p \mathrm{CO}_{2}$ and changing climate in the Arctic Ocean. Particular attention is paid to the strong regional variability within the Arctic, and, for comparison, simulation results are contrasted with those for the global ocean. Simulations were run to year 2099 using the RCP8.5 (an Intergovernmental Panel on Climate Change (IPCC) Fifth Assessment Report (AR5) scenario with the highest concentrations of atmospheric $\mathrm{CO}_{2}$ ). The separate impacts of the direct increase in atmospheric $\mathrm{CO}_{2}$ and indirect effects via impact of climate change (changing temperature, stratification, primary production and freshwater fluxes) were examined by undertaking two simulations, one with the full system and the other in which atmospheric $\mathrm{CO}_{2}$ was prevented from increasing beyond its preindustrial level (year 1860). Results indicate that the impact of climate change, and spatial heterogeneity thereof, plays a strong role in the declines in $\mathrm{pH}$ and carbonate saturation $(\Omega)$ seen in the Arctic. The central Arctic, Canadian Arctic Archipelago and Baffin Bay show greatest rates of acidification and $\Omega$ decline as a result of melting sea ice. In contrast, areas affected by Atlantic inflow including the Greenland Sea and outer shelves of the Barents, Kara and Laptev seas, had minimal decreases in $\mathrm{pH}$ and $\Omega$ because diminishing ice cover led to greater vertical mixing and primary production. As a consequence, the projected onset of undersaturation in respect to aragonite is highly variable regionally within the Arctic, occurring during the decade of 2000-2010 in the Siberian shelves and Cana-
\end{abstract}

dian Arctic Archipelago, but as late as the 2080s in the Barents and Norwegian seas. We conclude that, for future projections of acidification and carbonate saturation state in the Arctic, regional variability is significant and needs to be adequately resolved, with particular emphasis on reliable projections of the rates of retreat of the sea ice, which are a major source of uncertainty.

\section{Introduction}

The concentration of $\mathrm{CO}_{2}$ has been steadily rising in the atmosphere as a result of the burning of fossil fuels, cement manufacture and land-use changes (Friedlingstein et al., 2010). Further increases are expected on the basis of current emission rates, e.g. to $450-650 \mathrm{ppm}$ by the mid 21 st century (Peters et al., 2012). The ocean acts as a sink for this atmospheric carbon, with uptake estimated at $120-140 \mathrm{Pg} \mathrm{C}$ since preindustrial times (Sabine et al., 2004; Khatiwala et al., 2009). The invasion of $\mathrm{CO}_{2}$ into the ocean has two important consequences for seawater chemistry, namely that both $\mathrm{pH}$ and carbonate saturation state $(\Omega)$ decrease. The ocean biota, and especially calcifying organisms such as coccolithophores, foraminiferans and pteropods, are particularly vulnerable to these changes (Fabry et al., 2008; Gangstøet al., 2011).

In addition to the direct impact of $\mathrm{CO}_{2}$ invading the ocean, $\mathrm{pH}$ and saturation state are influenced by other aspects of changing climate, including temperature increase, changes in upper ocean mixing (including associated changes in net primary production), retreating sea ice and increasing freshwater input. A number of studies have examined the relative importance of the direct impact of invading $\mathrm{CO}_{2}$ and these other climate-related factors for the $\mathrm{pH}$ and $\Omega$ in the global ocean. McNeil and Matear (2007) remarked that temperature was 
the most important of the climate change factors. It has relatively little effect on $\mathrm{pH}$ because, although increasing temperature causes $\mathrm{pH}$ to decrease, it also buffers dissolved inorganic carbon (DIC) increase (and associated $\mathrm{pH}$ decrease) through the reduction in $\mathrm{CO}_{2}$ solubility. In contrast, carbonate saturation state, which is relatively insensitive to the direct effect of temperature, declines significantly because of increasing DIC in the ocean, despite the buffering effect of temperature. The implication is that future projections of surface ocean acidification $(\mathrm{pH})$ in the global ocean need only consider the direct effect of $\mathrm{CO}_{2}$ invading the ocean, whereas the temperature effect is more relevant regarding carbonate saturation state.

The Arctic is an area that is particularly sensitive to changing climate (Walsh et al., 2011) as a result of so-called polar amplification (Moritz et al., 2002). Observations have shown that a number of areas in the Arctic Ocean (AO) are already undersaturated with respect to aragonite (e.g. the Canada Basin: Yamamoto-Kawai et al., 2009; freshwater-influenced shelves: Chierici and Fransson, 2009; the Chukchi, Beaufort and eastern East Siberian seas: Bates et al., 2011). A number of modelling and observational studies have indicated that the Arctic Ocean, with its low temperatures, substantial freshwater input and fast retreating sea ice, is a region where the impact of ocean acidification is likely to manifest itself first (McNeil and Matear, 2007; Yamamoto-Kawai et al., 2009; Yamamoto et al., 2012, Steinacher et al., 2009; Bates et al., 2011). Future declines in $\mathrm{pH}$ and $\Omega$ have been shown to closely track changes in atmospheric $\mathrm{CO}_{2}$. The equilibration between oceanic and atmospheric $\mathrm{CO}_{2}$ follows the well-established carbonate chemistry of sea water, with only a relatively minor impact by the changing ocean physics in nearly all ocean regions except for the Arctic Ocean (e.g. Yamamoto et al., 2012; McNeil and Matear, 2007). The fast retreat of sea ice leads to the exposure of previously undersaturated (with respect to $\mathrm{CO}_{2}$ ) areas to the atmosphere, accelerating its absorption by the ocean. Other potential impacts include changes in stratification with consequences for nutrient supply and primary productivity (e.g. Popova et al., 2010), and the effect of freshwater input (Chierici and Fransson, 2009).

Various climate-related impacts on ocean acidification have been included in modelling studies, and have indicated that the Arctic Ocean will become undersaturated with respect to aragonite by the 2040s (e.g. Steinacher et al., 2009; Yamamoto et al., 2012). These studies generally assessed the impact of acidification in the Arctic on the basis of basinaveraged or zonal characteristics. The Arctic Ocean is, however, an area with large spatial gradients in physical and biological properties (e.g. Carmack et al., 2006; Popova et al., 2010); even more importantly, it is an area where climate change factors are expected to have strong regional variations. In this paper we focus on regional aspects of Arctic Ocean acidification, with two main aims. First, using a global ocean general circulation model (OGCM), we in- vestigate the direct (invasion of $\mathrm{CO}_{2}$ ) and indirect (climaterelated) effects of increasing atmospheric $\mathrm{CO}_{2}$ (changes in temperature, stratification, sea ice cover and freshwater input) on $\mathrm{pH}$ and saturation state in the Arctic Ocean, undertaking an intercomparison with the rest of the global ocean. The OGCM includes a full representation of the carbon cycle and is forced by the atmospheric $\mathrm{CO}_{2}$ concentration through the period 1860-2099 from an Earth system model run under the RCP8.5 scenario (Jones et al., 2011). This run is described and analysed in detail for the global ocean by Yool et al. (2013b). The second aim is to study the heterogeneity of acidification and carbonate saturation state in the Arctic as projected by the model, and to relate it to the variability in underlying factors. The direct and indirect effects are distinguished by comparing two parallel simulations of the model. The first run is that described above, where the ocean carbon system experiences both increasing atmospheric $\mathrm{CO}_{2}$ and the resulting climate impacts on ocean physics and biology. The second simulation separates $\mathrm{CO}_{2}$ and climate by holding atmospheric $\mathrm{CO}_{2}$ constant at the year 1860 value while continuing to allow climate change.

Recent modelling studies analysing the output of multimodel experiments have found significant inter-model differences in the Arctic Ocean (e.g. Steinacher et al., 2010; Popova et al., 2012, Steiner et al., 2014). Thus care should be taken when interpreting the results presented in this study in view of the uncertainty in the projected changes. Although this study presents a detailed analysis of underlying physical and biogeochemical mechanisms, it is based on a single model and is therefore less robust than those based on multimodel projections, e.g. Tebaldi and Knutti (2007).

\section{Method}

The Nucleus for European Modelling of the Ocean (NEMO) model is comprised of an ocean general circulation model, OPA (Madec, 2008), coupled with the Louvain-la-Neuve Ice Model v2, LIM2 (Timmermann et al., 2005). NEMO version 3.2 is used here, which has a horizontal resolution of $1^{\circ}$ and a vertical resolution of 64 levels achieving resolution of $5 \mathrm{~m}$ in the top $20 \mathrm{~m}$ of the water column. The model is configured on tri-polar grid (e.g. Murray , 1996) with the two northern model poles in Siberia and in the Canadian Arctic Archipelago and the southern model pole in the geographical South Pole. The horizontal resolution of the grid is 1 geographical degree (111 km resolution) at the Equator and increases polewards due to grid convergence. This results in the resolution of $35-55 \mathrm{~km}$ in the Arctic Ocean with the highest resolution in the Canadian Arctic Archipelago. Vertical mixing is parameterised using the turbulent kinetic energy scheme of Gaspar et al. (1990). NEMO is forced by the output from a simulation of the HadGEM2-ES Earth system model run by the UK Meteorological Office (UKMO) that includes representations of the terrestrial and oceanic carbon 
cycles, atmospheric chemistry and aerosols (Collins et al., 2011). The HadGEM2-ES simulation used here, identifier AJKKH, was performed as part of the UKMO's input (Jones et al., 2011) to the Coupled Model Intercomparison Project 5 (CMIP5) and Assessment Report 5 (AR5) of the Intergovernmental Panel on Climate Change (IPCC). The frequency of output fields is monthly for precipitation (rain, snow, runoff), daily for radiation (downwelling short- and long-wave) and 6 hourly for the turbulent variables (air temperature, humidity and wind velocities). Biogeochemical model is forced by the atmospheric $\mathrm{CO}_{2}$ concentrations of the HadGEM2-ES run under the RCP8.5 scenario (Yool et al., 2013b). A caveat of such an approach is that the atmospheric $\mathrm{CO}_{2}$ we use for the forcing was affected by the HadGEM2-ES ocean model, which is not consistent with the ocean physics and biogeochemistry of the model used in this study.

In order to separate the impacts of rising atmospheric $\mathrm{CO}_{2}$ from those of changing climate (imposed on the ocean model through the boundary conditions of physical variables), we perform a second simulation in which atmospheric $\mathrm{CO}_{2}$ is held constant at the value for year 1860 while continuing to allow climate change.

Biogeochemistry in NEMO is represented by the plankton ecosystem model MEDUSA (Model of Ecosystem Dynamics, carbon Utilisation, Sequestration and Acidification; Yool et al., 2011, 2013a). This is a size-based, intermediatecomplexity model that divides the plankton community into "small" and "large" portions and which resolves the elemental cycles of nitrogen, silicon and iron. The small portion of the ecosystem is intended to represent the microbial loop of picophytoplankton and microzooplankton, while the large portion covers microphytoplankton (specifically diatoms) and mesozooplankton. The intention of MEDUSA is to separately represent small, fast-growing phytoplankton that are kept in check by similarly fast-growing protistan zooplankton and large, slower-growing phytoplankton that are able to temporarily escape the control of slower-growing metazoan zooplankton. The non-living particulate detritus pool is similarly split between small, slow-sinking particles that are simulated explicitly and large, fast-sinking particles that are represented only implicitly. See Yool et al. (2013a) for a full description of the model. The riverine input of all biogeochemical state variables is prescribed through a noflux boundary condition similar to that of temperature, where river water implicitly has the same concentrations as the seawater it mixes into. Note that $\Omega$ is calculated as a function of salinity, which is zero in the riverine water (Yool et al., 2013b). Concentration of all biogeochemical state variables in the rain, snow and ice melt water is assumed to be zero. The model does not account for the glacier melt.

Model performance with respect to ecosystem dynamics of the present-day Arctic Ocean was assessed by Popova et al. $(2010,2012,2013)$ and globally by Yool et al. (2011). Model performance with respect to the global ocean carbon cycle is described in Yool et al. (2013a, b). For the Arctic
Ocean we note good agreement of modelled values of surface saturation with respect to calcite $\left(\Omega_{\mathrm{c}}\right)$, and aragonite $\left(\Omega_{\mathrm{a}}\right)$ with values reported by Jutterström and Anderson (2005) for the central Arctic Ocean (1.9-2.7 for $\Omega_{\mathrm{c}}$ and 1.1-1.8 for $\Omega_{\mathrm{a}}$ measured during 1990s). Over the shelves of the western Arctic Ocean and Baffin Bay the modelled values are in the same range as observations reported by Chierici and Fransson (2009) (8.0-8.2 for $\mathrm{pH}_{\mathrm{SWS}}$, where SWS denotes sea water scale units; $1.8-3.0$ for $\Omega_{\mathrm{c}} 1.8-2.0$ for for $\Omega_{\mathrm{a}}$ ); however we note that the model underestimates high values of $\Omega_{\mathrm{c}}$ and $\Omega_{\mathrm{a}}$ in the Chukchi Sea (4 and 2.5 as reported by Chierici and Fransson, 2009, and Bates et al., 2012) by about 1 unit.

In Sect. 3.3 we evaluate the sensitivity of our main results to uncertainties in the parameterisations of the main factors that control them with a focus on the rate of sea ice decline and ocean mixing. Variation in the rate of ice decline is achieved by varying (i) albedo of snow/ice surface, (ii) bulk sea ice salinity, and (iii) partitioning between basal and lateral oceanic heat fluxes towards sea ice. The albedo experiments introduce two sensitivity cases to the control simulations, the faster ice melting and the slower ice melting. In the former case, following Shine and Henderson-Sellers (1985) albedo formulation, we decrease the albedo for the snow/ice classes to 0.60 for frozen bare ice, to 0.40 for melting ice, to 0.75 for dry and 0.52 for thick melting snow (the control run uses values of $0.72,0.50,0.80$ and 0.65 respectively). To slow down sea ice melting, the above parameters are taken as $0.72,0.58,0.87$ and 0.70 . The ranges of the albedo variations are designed to emulate changes in the surface properties of the snow and ice cover.

Variation in ocean mixing is obtained by simultaneously changing (i) background diffusivity and (ii) the coefficient of the surface input of turbulent kinetic energy (TKE); details of the mixing scheme used here are given by Gaspar et al. (1990) and Madec (2008). The effective changes of mixing parameters were constrained to those areas where sea ice was present. This was done in order to avoid upstream effects especially in the Pacific sector - if open ocean mixing parameters were varied on a global basis. In order to reduce vertical diffusivity under sea ice, the background vertical diffusivity of $10^{-6} \mathrm{~m}^{2} \mathrm{~s}^{-2}$ was scaled down by a factor of 10 and the coefficient of the surface input of TKE was reduced from 3.75 (control) to 1. This was done in order to emulate the shielding of the ocean from wind and waves by compact ice. For the experiment with increased vertical mixing, the coefficient of the surface input of TKE was increased to 60 , assuming the same value as for the ocean. The rational for these changes is the introduction of mixing - driven by direct wind action and breaking waves - where sea ice cover is reduced. 

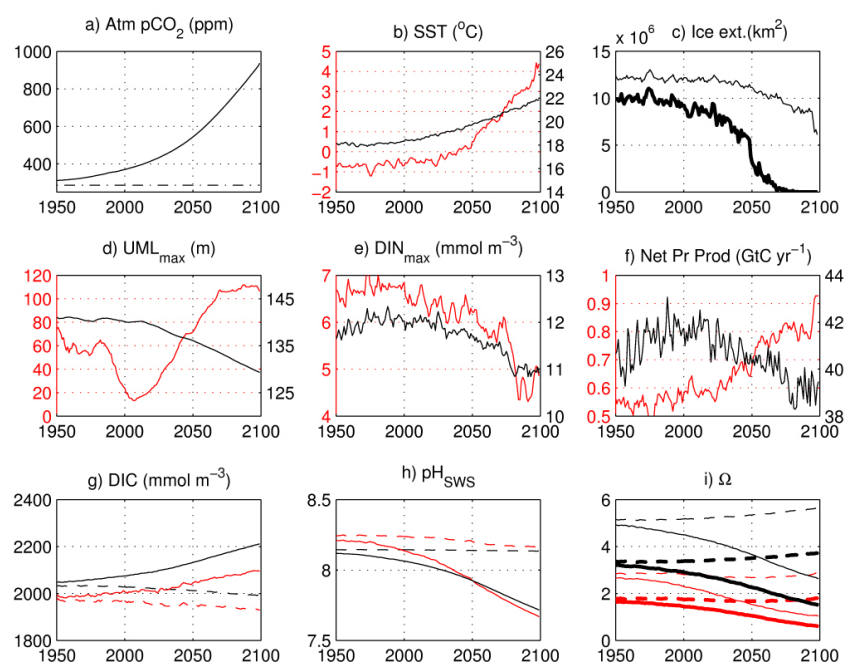

Fig. 1. Time evolution of modelled characteristics for the global ocean (black line and font) and the Arctic Ocean (treated as north of $66^{\circ} \mathrm{N}$, red line and font): (a) atmospheric $\mathrm{CO}_{2}$ (ppm) from the forcing Earth system model; (b) sea surface temperature $\left({ }^{\circ} \mathrm{C}\right)$; (c) extent of the Northern Hemisphere sea ice $\left(\mathrm{km}^{2}\right)$ for September (thick line) and March (thin line); (d) maximum depth of the upper mixed layer UML, (m); (e) annual maximum surface dissolved inorganic nitrogen (DIN, $\left.\mathrm{mmol} \mathrm{m}^{-3}\right)$; (f) water-column-integrated net primary production $\left(\mathrm{gC} \mathrm{yr}^{-1}\right)$; $(\mathrm{g})$ surface DIC $\left(\mathrm{mmolm}^{-3}\right)$; (h) $\mathrm{pH}_{\mathrm{SWS}}$; (i) $\Omega_{\mathrm{c}}$ and $\Omega_{\mathrm{a}}$. Annual mean characteristics are given for all properties unless otherwise specified. For (g-i) dashed lines refer to the "climate-effect" run (no $\mathrm{CO}_{2}$ increase); for (i) thin line refers to $\Omega_{\mathrm{c}}$, thick line refers to $\Omega_{\mathrm{a}}$.

\section{Results}

\subsection{Regional aspects of Arctic Ocean acidification}

Under the RCP8.5 scenario, atmospheric $\mathrm{CO}_{2}$ in the HadGEM2-ES model (used here as forcing) reaches $950 \mathrm{ppm}$ by the end of the century. Projected by NEMO, globally averaged SST (sea surface temperature) rises from 18 to $22{ }^{\circ} \mathrm{C}$ during the same period (Fig. 1a, b). This increase is more pronounced in the Arctic Ocean (defined here as north of $66^{\circ} \mathrm{N}$ ) due to polar amplification (Moritz et al., 2002), with SST changing from -1 to $4.5^{\circ} \mathrm{C}$ (Fig. 1b). The associated decline of sea ice leads to virtually ice-free conditions in summer in the Arctic Ocean from the 2060s onwards (Fig. 1c).

Ice retreat is the factor that most strongly influences the spatial distribution of the projected declines of $\mathrm{pH}_{\mathrm{SWS}}$ and $\Omega$ in the Arctic Ocean (e.g. McNeil and Matear, 2007). This is a result of increasing ocean uptake of $\mathrm{CO}_{2}$, freshening of the surface layers by melt of the perennial ice and the deepening of winter mixing. Modelled annual mean sea ice concentration for years 2000 and 2099 is shown in Fig. 2a and b. Seasonally ice-free conditions in the Arctic Ocean occur during the decade of the 2060s. By the end of the 21st century, the
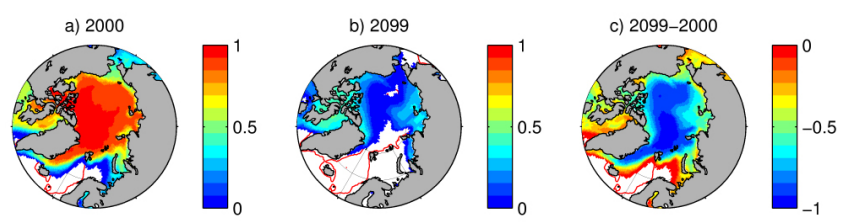

Fig. 2. Arctic Ocean annual mean ice concentration for year 2000 (a), 2099 (b), difference between year 2099 and 2000 (c). The red line on this and subsequent Arctic plots shows $500 \mathrm{~m}$ bathymetric contour.
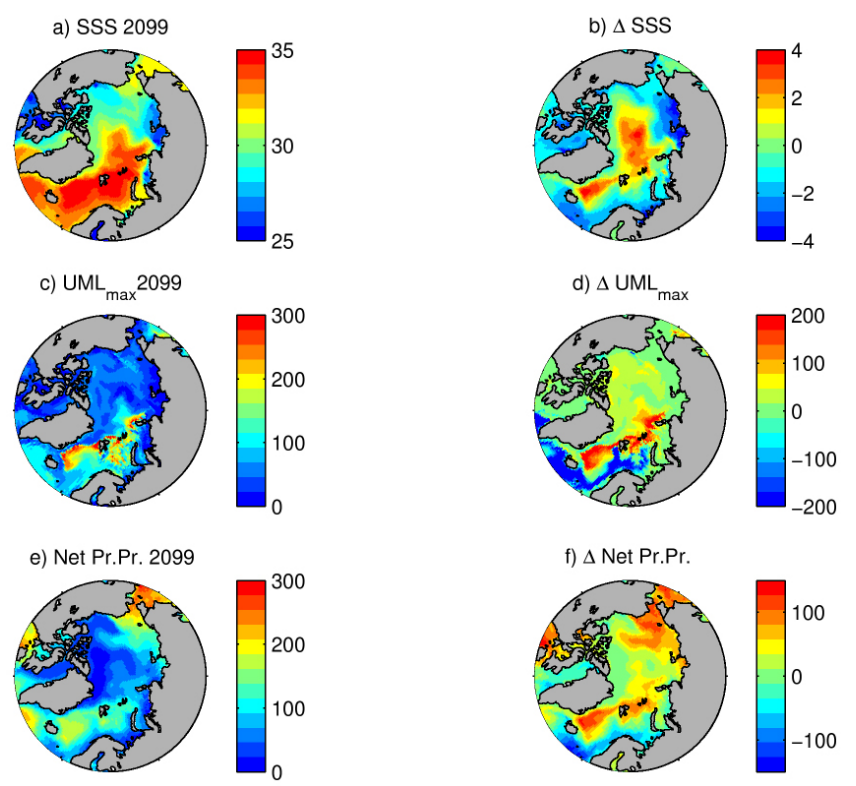

Fig. 3. Arctic Ocean surface salinity (a, b), maximum upper mixed layer depth (UML) (c, d) in $\mathrm{m}$, net primary production $(\mathbf{a}-\mathbf{c})$ in $\mathrm{gC} \mathrm{m}^{-2} \mathrm{yr}^{-1}$. The first column shows values for year 2099; the second column shows deviation between year 2099 and year 2000.

central Arctic Ocean becomes nearly ice-free on an annual basis and winter ice occurs only on the Siberian and Canadian shelves, including Baffin Bay (Fig. 2b). The retreat of the ice brings substantial changes to projected surface salinity (Fig. 3a, b), with a strong decline over the shelves of the western Arctic Ocean and in Baffin Bay of up to 3 driven by the accumulation of the melt water. The second major area of salinity decline is the Siberian shelves (up to 4 due to the increase in riverine input). In the areas which change from being permanently ice-covered to permanently ice-free (the central Arctic Ocean), surface salinity increases by about 34. In addition, an increase in surface salinity occurs in areas of deepening winter mixing, mostly associated with Atlantic inflow (Fig. 3c, d).

We chose the maximum annual depth of the upper mixed layer (based on monthly mean values) as a convenient measure of mixing in the upper part of the water column. This is important for ecosystem functioning, as well as the rate 
of acidification, since it controls exchange with deeper layers that have higher salinity, temperature, nutrients, and DIC. During the simulation, winter mixing deepens over the majority of the Arctic Ocean (Fig. 3c, d), with the exception of the Norwegian and western Barents seas, where ocean warming induces shallowing of winter mixing by more than $200 \mathrm{~m}$. The greatest deepening of winter mixing occurs in areas of increased Atlantic inflow into the Arctic Ocean, namely the Greenland Sea and the outer shelves of the Barents, Kara and Laptev seas, where deep mixing by the end of the century penetrates to $200-300 \mathrm{~m}$.

The areas experiencing the largest changes in ice regime (from permanent ice cover as it is today to a year-round ice-free zone by 2099) and substantial freshening show the largest decreases in $\mathrm{pH}_{\mathrm{SwS}}$ from 8.2 to 7.65 (central Arctic Ocean, Canadian Arctic Archipelago and Baffin Bay, Fig. $4 \mathrm{a}, \mathrm{b}$ ), $\Omega_{\mathrm{c}}$ from 2 to 1 (Fig. $4 \mathrm{e}, \mathrm{f}$ ) and $\Omega_{\mathrm{a}}$ from 1.2 to 0.5 (Fig. 4i, j). The largest increase in DIC is also seen in the central $\mathrm{AO}$ (Fig. 4m, n) due to equilibration with the atmosphere following the loss of permanent ice cover. About half of this increase (100-110 out of $220 \mathrm{mmol} \mathrm{m}^{-3}$ ) happens as a result of the climate change impact driving retreat of the ice (Fig. 4o, p).

Now we aim to achieve more quantitative estimates of the role of various factors across the Arctic Ocean. This requires us to more formally define the boundaries of the Arctic domains where the relative importance of these factors is different. $\mathrm{pH}_{\mathrm{SwS}}$ and $\Omega$ are dependent on total alkalinity (Alk), DIC, temperature $(T)$ and salinity $(S)$. Each of these variables is affected by freshwater input and by advective and diffusive processes. Alk and DIC are also modified by the ocean biota (e.g. photosynthesis, respiration, calcification), while DIC is additionally affected by air-sea gas exchange. In this section we estimate which processes are most responsible for changes in $\mathrm{pH}_{\mathrm{SWS}}$ and $\Omega$ over the period 2000 2099, and how their relative contributions vary across the Arctic Ocean. The processes identified are air-sea gas exchange, freshwater input, vertical mixing, advection, horizontal diffusion, biological process, and changes in $T$ and $S$. Note that, in the case of changes in $T$ and $S$, we consider their total impact on $\mathrm{pH}_{\mathrm{SWS}}$ and $\Omega$ without separation between advection, diffusion and fluxes at the ocean-atmosphere boundary. We evaluate the contributions of each of these processes in the upper $100 \mathrm{~m}$ for every model grid point of the Arctic Ocean, following the approach of Yamamoto et al. (2012). However, unlike this study, here we obtain spatial distributions of the factors in question, rather than total Arctic budgets.

The spatial distributions of the contributing factors (results not shown) show strong regional variability that broadly forms four distinctive provinces, each manifesting qualitatively different flux balances. The spatial extents of these provinces are shown in Fig. 5a. Specifically, we define the following provinces: (1) Siberian shelves (areas of less than $220 \mathrm{~m}$ depth in the Kara, Laptev, East Siberian and Chukchi seas); (2) Atlantic inflow (areas where diffusivity makes a substantial contribution to the $100 \mathrm{~m}$ budget imposing decline of $\Omega_{\mathrm{a}}$ in excess of 0.1); (3) Nordic minimum (area of minimum $\Omega_{\mathrm{a}}$ changes in the Arctic Ocean over the century, defined as areas where these changes do not exceed 0.9); and (4) freshwater province (areas where freshwater fluxes play dominant role in the $\Omega_{\mathrm{a}}$ changes, defined as areas not covered by $\mathrm{i}-\mathrm{iii})$. Although some of the exact numerical definitions of the domain boundaries are somewhat subjective, we find these selection criteria to be most successful at delineating the qualitative differences across the AO.

Projected changes in $\Omega_{\mathrm{a}}$ between year 2000 and 2099 for the Arctic Ocean (defined as north of $66^{\circ} \mathrm{N}$ ) and the four provinces defined above are shown in Fig. 5b. As described previously, Fig. $5 \mathrm{~b}$ also breaks this total change down into contributions due to the process described above except for horizontal diffusion and those due to changes in $T$ and $S$ which were found to be negligible.

Decline of $\Omega_{\mathrm{a}}$ over the Siberian shelves occur slower than in other provinces with the exception of Nordic minimum. However, by 2099 values of $\mathrm{pH}_{\mathrm{SwS}}$ and $\Omega$ are lower than those in the central Arctic Ocean since present-day $\mathrm{pH}_{\mathrm{SWS}}$ and $\Omega$ are already low in this area. Thus, by 2099 surface $\mathrm{pH}_{\mathrm{SWS}}$ is as low as 7.6, while typical values $\Omega_{\mathrm{c}}$ and $\Omega_{\mathrm{a}}$ are 0.8 and 0.4 respectively. In these areas, the impact of airsea gas exchange is relatively low due to high concentrations of DIC, while those of vertical diffusivity and freshwater from ice melt, which strongly reduce $\Omega_{\mathrm{a}}$ in other provinces, are nearly negligible. The main factor reducing $\Omega_{\mathrm{a}}$ in this province is horizontal advection of riverine water, which is nearly compensated for by the biological pump (Fig. 5b).

The Atlantic inflow province is characterised by strong decreases in $\Omega_{\mathrm{a}}$ driven by vertical diffusivity, horizontal advection and air-sea gas exchange, with a relatively weak compensating effect of the biological pump (Fig. 5b). Although the rate of change in $\Omega_{\mathrm{a}}$ over the century in this province is the highest in the Arctic Ocean, this area is projected to remain oversaturated by the end of the century in respect to aragonite due to its high present-day values (Fig 4m, n, o) influenced by the upstream North Atlantic.

The Nordic minimum province was identified on the ground of slowest changes in the $\Omega_{\mathrm{a}}$. All of these decline over the 21 st century and are clearly buffered by the physical changes (cf. Fig. 4 panels $g$ and h, k and l, and o and p). We note that this province is also characterised by a substantial deepening of winter mixing (Fig. 3d). Analysis of the budget fluxes shows that, in spite of this deepening, vertical diffusivity does not play a major role in controlling $\Omega_{\mathrm{a}}$ directly. Instead, the low rate of $\Omega_{\mathrm{a}}$ decline is driven here by relatively low air-sea gas exchange (due to already high concentrations of DIC), the lack of freshwater input into this area and low advective fluxes. In short, the budget is similar to that of the Siberian shelves except for the impact there of riverine inputs which act to lower $\Omega_{\mathrm{a}}$ in shelf waters. 
a) $\mathrm{pH}_{\text {SWS }}$ yr 2001

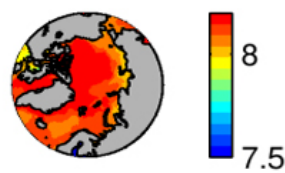

e) $\Omega_{c}$ yr 2001

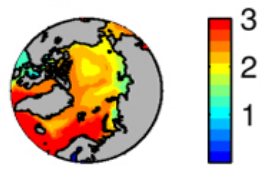

i) $\Omega_{\mathrm{a}} 2001$

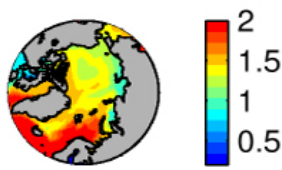

m) DIC 2099

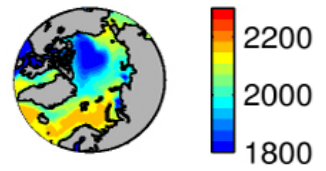

b) $\mathrm{pH}_{\text {sws }}$ yr 2099

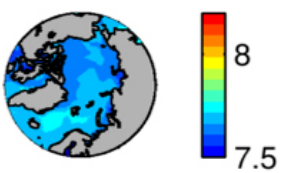

f) $\Omega_{\mathrm{c}} \mathrm{yr} 2099$

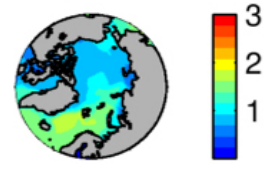

j) $\Omega_{\mathrm{a}} 2099$

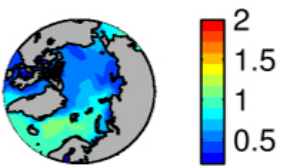

n) DIC 2099

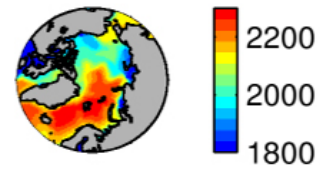

c) $\Delta \mathrm{pH}_{\mathrm{sws}}$

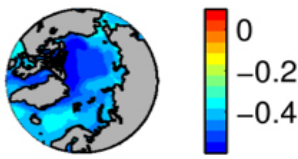

g) $\Delta \Omega_{\mathrm{c}}$

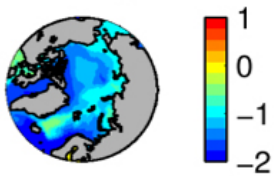

k) $\Delta \Omega$

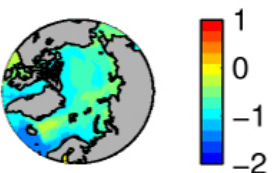

o) $\Delta \mathrm{DIC}$

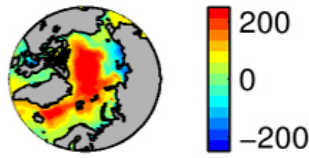

d) $\Delta \mathrm{pH}_{\mathrm{sws}}$ (climate)

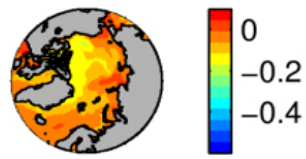

h) $\Delta \Omega_{\mathrm{c}}$ (climate)

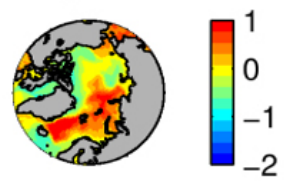

I) $\Delta \Omega_{\mathrm{a}}$ (climate)

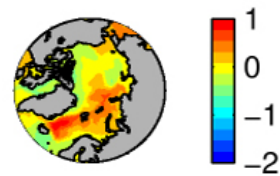

p) $\Delta$ DIC (climate)

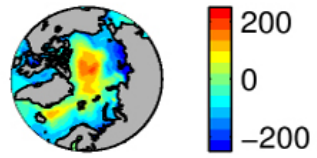

Fig. 4. Arctic Ocean $\mathrm{pH}_{\mathrm{SWS}}(\mathbf{a}-\mathbf{d}), \Omega_{\mathrm{c}}(\mathbf{e}-\mathbf{h}), \Omega_{\mathrm{a}}(\mathbf{i}-\mathbf{l}), \mathrm{DIC}\left(\mathrm{mmolm}^{-3}, \mathbf{m}-\mathbf{n}\right)$. The first and second columns shows values for year 2000 and 2099 respectively, the third column shows deviation between year 2099 and year 2000 for the full run, and the fourth column shows deviation between year 2099 and year 2000 for the for the climate change run.

As can be seen from Fig. 5a, the freshwater province occupies the central Arctic Ocean, the Canadian Arctic Archipelago, Baffin Bay and the Greenland Sea. These areas experience the largest changes in the ice regime, from near-permanent ice cover today through to year-round icefree conditions by 2099. Freshwater flux is the largest contributing factor in the decline of $\Omega_{\mathrm{a}}$ within this province, though this is largely counterbalanced by advective fluxes since the province also includes the main areas of AO outflow. Gas exchange also plays substantial role in reducing $\Omega_{\mathrm{a}}$ following the loss of the permanent ice cover that previously prevented equilibration with the atmosphere. The province maintains its very stable stratification across the 21 st century such that vertical diffusivity does not significantly contribute to the $100 \mathrm{~m}$ balance. A further notable feature is the compensating effect of the biological pump which increases with productivity over some of the province as it transitions across the 21 st century to an ice-free state.

In summary, these results indicate climate change has pronounced, if regional, impacts on $\Omega$ in the Arctic Ocean. Factors such as freshwater input from melting of (previously) permanent ice cover, advection of riverine freshwater and vertical diffusive fluxes vary strongly spatially and result in regionally variable impacts in the decline of $\Omega_{\mathrm{a}}$. Although not presented here, a similar budget analysis for $\mathrm{pH}_{\mathrm{SWS}}$ shows similar variability across the main domain with an additional impact of temperature dependence (McNeil and Matear, 2007). In some regions of the Arctic Ocean, climate change increases the decline of $\mathrm{pH}_{\mathrm{SwS}}$ and $\Omega$ by up to factor of 2 relative to rising atmospheric $\mathrm{CO}_{2}$. Meanwhile, in other areas it nearly cancels (buffers) changes induced by rising $\mathrm{CO}_{2}$. Thus, processes driven by climate change create strong gradients in the rates of decline of $\mathrm{pH}_{\mathrm{SWS}}$ and $\Omega$ across the basin.

\subsection{Timing of the first occurrence of undersaturation conditions in the Arctic Ocean}

By 2099, the model projects that surface waters of the Arctic Ocean will be undersaturated with respect to aragonite in all areas (Fig. 4j). Some areas, however, escape undersaturation with respect to calcite, including the areas of the Arctic Ocean affected by Atlantic inflow: Greenland, Norwegian and Barents seas and the outer shelves of the Kara Sea (Fig. 4f). As undersaturation may impact calcifying 

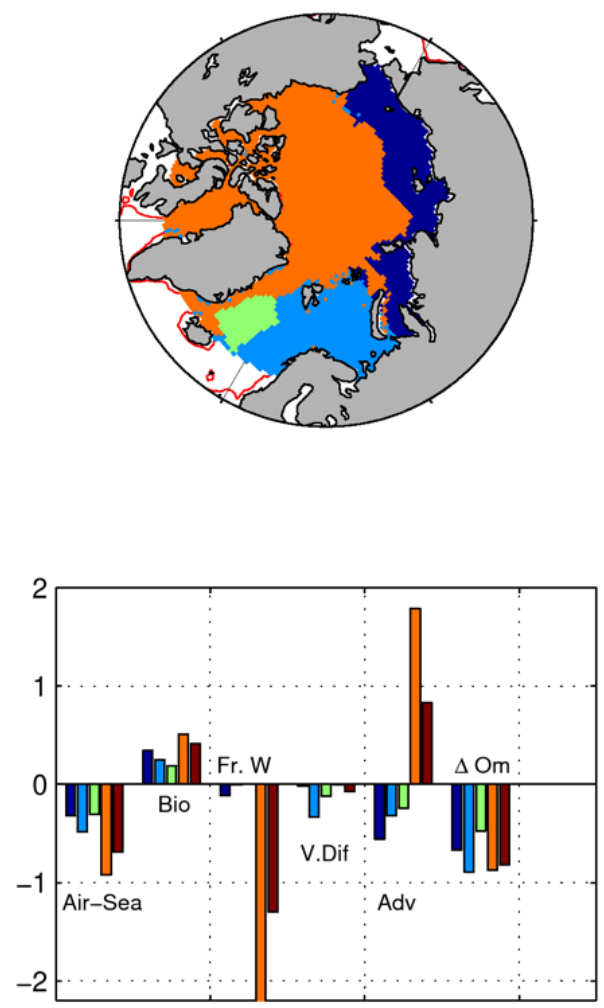

Fig. 5. (a) Spatial extent of four provinces showing qualitatively different balance of the main factors contributing to the $\Omega_{\mathrm{a}}$ decline over the 21 st century and identified as Siberian shelves (dark blue), Atlantic inflow (light blue), Nordic minimum (green), freshwater province (orange) - see text; (b) projected changes in the annual mean difference in $\Omega_{\mathrm{a}}$ from 2000 to 2099 in the top $100 \mathrm{~m}$ of the Arctic Ocean (north of $66^{\circ} \mathrm{N}$, dark red bars) and four province shown in (a). The total change $(\Delta \mathrm{Om})$ is divided into contribution by air-sea gas exchange (Air-Sea), biology (Bio), freshwater fluxes (Fr.W), vertical diffusivity (V.Dif), and advection (Adv).

marine organisms such as shellfish that form the basis of regional fisheries, it is crucial to estimate the time of the onset of undersaturation. The year of first occurrence of monthly mean undersaturated surface waters with respect to calcite and aragonite under the RCP8.5 scenario is shown in Fig. $6 \mathrm{a}$ and $\mathrm{b}$, while the same characteristic for shelf bottom waters is shown in Fig. 6c and d. With respect to aragonite, undersaturation of both surface and bottom waters is already widespread at the Siberian shelves, Canadian Arctic Archipelago and part of the Beaufort Sea affected by the McKenzie River. The surface of the Beaufort Gyre becomes undersaturated before 2020, followed by widespread undersaturated conditions in the central Arctic before 2040. Areas affected by the Atlantic inflow become undersaturated last, during the 2080s.

In the case of calcite, undersaturation in the surface occurs 20-30 yr later than that of aragonite, and follows the same spatial progression (Fig. 6a, c). Siberian shelves become un-
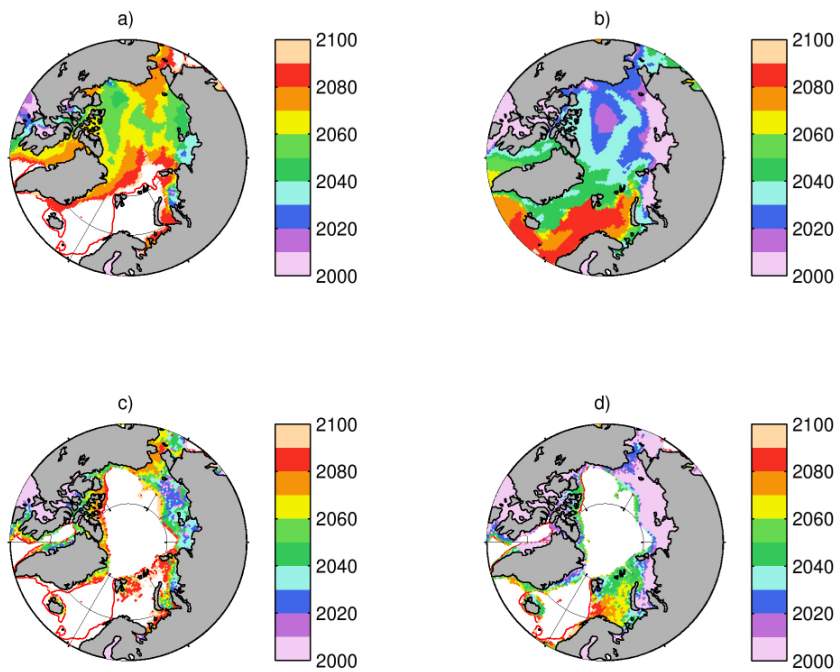

Fig. 6. The first occurrence of a monthly mean undersaturated surface waters in respect to calcite (a) and aragonite (b, years). The same for the shelf bottom waters at the depth of the deepest model vertical grid box (c, d).

dersaturated first, starting from the inner shelves of the Kara and Laptev seas and Canadian Arctic Archipelago, followed by the central Arctic Ocean. Areas affected by the Atlantic inflow (Greenland, Norwegian and Barents seas) do not show undersaturation within the 21 st century. Shelf bottom water shows a similar timing of calcite undersaturation, except for the East Siberian Sea, where undersaturation at the bottom occurs nearly two decades earlier than at the surface.

The timing of the onset of undersaturated conditions presented in this section is based on the first occurrence of a monthly mean undersaturated value. The season in which such conditions are likely to first occur depends on the amplitude and phase of the annual cycle. Our results find that, relative to the projected change through the century, the annual amplitude of $\Omega_{\mathrm{a}}$ is relatively low in the central AO (approximately $0.1-0.2$ ), though higher (approximately $0.3-0.4$ ) in areas affected by Pacific or Atlantic inflow. This amplitude remains nearly unchanged through the 21 st century even in the face of large absolute change in $\Omega_{\mathrm{a}}$ during this period. However, the phase of the annual cycle varies strongly, both in space across the basin and in time through the 21 st century. Fig. 7 shows the timing of minimum annual values (month number) across the Arctic Ocean for years 2000, 2050 and 2099. As the Arctic Ocean progresses into an ice-free state towards the end of the century, the phase of the annual cycle in $\Omega_{\mathrm{a}}$ becomes similar to that at mid-latitudes with a minimum in late summer and a maximum in winter-early spring. This pattern is driven by high values of DIC in winter and low values in summer driven by temperature-linked air-sea exchange, winter mixing and high summer biological production. The situation is more geographically complex during the first half of the century (Fig. 7a, b, ) when annual 
a) Year 2000

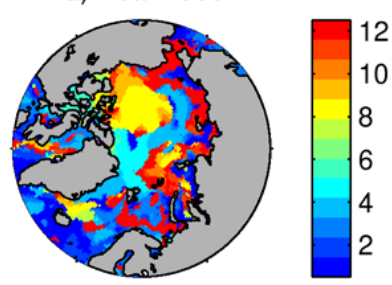

b) Year 2050

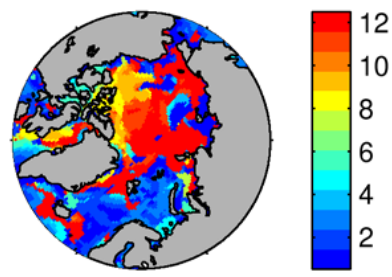

c) Year 2099

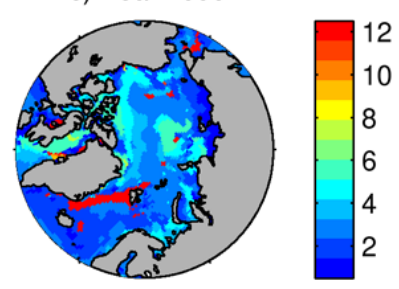

Fig. 7. Number of the month (January $=1$ ) in which minimum annual values of $\Omega_{\mathrm{a}}$ occur in year 2000 (a), 2050 (b) and 2099 (c).

minima across the $\mathrm{AO}$ occur throughout the year. The study of Steinacher et al. (2009) found that latitudinally averaged seasonality in the Arctic Ocean is generally out of phase with the seasonal signal in the rest of the northern hemisphere due to the impact of freshwater input from melting sea ice. Our results show a similar trend to that found by Steinacher et al. (2009) in the areas most affected by freshwater input from melting ice, but the opposite situation in areas of Pacific or Atlantic inflow. A transitional zone exists between these areas which is influenced by strong temporal and/or regional differences in the depth of winter mixing. In summary, projecting the season in which one might expect undersaturation conditions to first occur in the Arctic Ocean is a complex issue driven in part by future climate change but also by the underlying complexity in the spatial and temporal variability of the phase of the $\Omega_{\mathrm{a}}$ annual cycle.

\subsection{Sensitivity experiments}

In this section we evaluate the sensitivity of our main results to uncertainties in the parameterisations of the main factors that control them. The high computational cost of global model runs (even at relatively modest resolution) permits us to focus only on the major physical processes that affect rates of acidification but which are known to be poorly constrained in the climate models. Namely the rate of the decline of Arctic sea ice and oceanic vertical mixing (e.g. Yamamoto et al., 2012, Popova et al., 2012). With this purpose in mind, we performed four additional sensitivity experiments: (1) faster ice decline; (2) slower ice decline; (3) lower mixing; and (4) higher mixing.

The numerical experiments were run for $100 \mathrm{yr}$, starting from the control run state corresponding to the year 2000 . Both sets of sensitivity experiments (variation in the rates of ice decline and vertical mixing) lead to substantial modifications to both Arctic Ocean physics and biogeochemistry. We focus our attention here on the sensitivity of the projected first occurrence of the undersaturated - with respect to aragonite - surface waters (Fig. 6b), henceforth referred to as "undersaturation onset" for brevity.

The temporal evolution of Northern Hemisphere minimum ice extent (September) and Arctic-averaged $\Omega_{\mathrm{a}}$ for the control and numerical experiments are shown in Fig. 8a and b. In the ice decline simulations, the Arctic Ocean becomes seasonally ice-free approximately $15 \mathrm{yr}$ earlier or later than in the control run. Values of Arctic-averaged $\Omega_{\mathrm{a}}$ are lower in the simulations with faster ice decline or lower diffusivity (and marginally higher with slower ice decline or higher diffusivity), although the deviation between the control run and experiments does not exceed 0.05 (Fig. 8a, b) in the first half of the century and becomes negligible in the second half.

However, as Fig. 8c-f show, the regional variability of the differences in undersaturation onset between the control run and the sensitivity experiments is substantial. The area most sensitive to the change in the rate of ice decline is the Beaufort Gyre, showing acceleration of the undersaturation onset by about $20 \mathrm{yr}$, especially at its periphery in the case of faster ice decline. In the case of slower ice decline, the centre of the gyre shows a delay in undersaturation onset of approximately similar duration. The Beaufort Gyre manifests similarly high sensitivity in the experiments with variable vertical diffusivity (Fig. 8e,f). In the lower diffusivity run (Fig. 8e), undersaturation onset occurs about 10-20 yr earlier, with the maximum of the signal again at the periphery of the gyre. Meanwhile, in the higher diffusivity experiment (Fig. 8f), it occurs about $8-12$ yr later with the maximum signal located instead in the centre of the gyre.

Strong sensitivity of the Beaufort Gyre to the changes in both sensitivity analyses is linked to the accumulation of freshwater in the Arctic Ocean within this region, although the mechanisms underlying the changes are different. In the ice decline experiments, lower ice concentration leads to a spin-up of the BG that is clearly visible in the intensification of the sea surface height maximum in this area (results not shown), as well as accumulation of more freshwater and a corresponding reduction in salinity. This link between decreased ice cover and acceleration of the Beaufort Gyre has previously been described by Giles et al. (2012). By contrast, in the reduced diffusivity experiments, salinity decreases over the majority of the Arctic Ocean because 

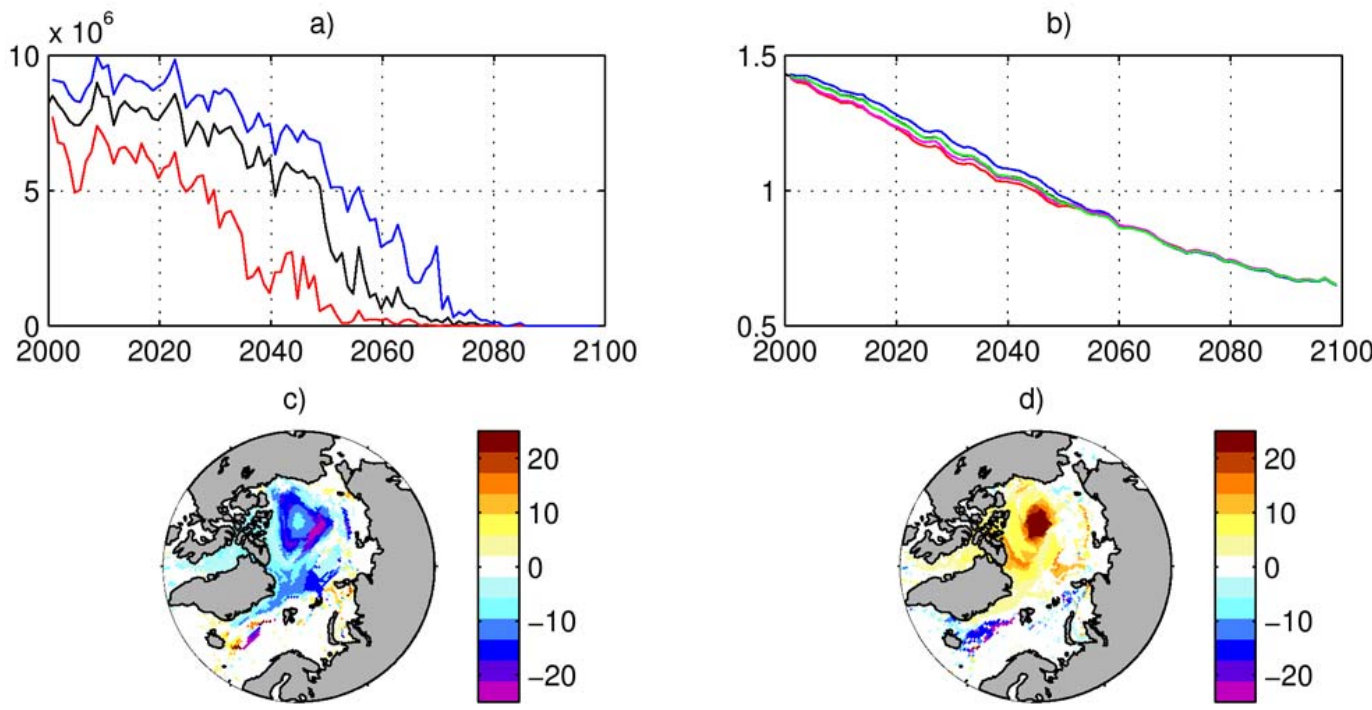

e)

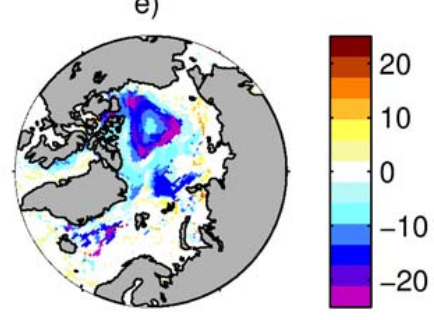

f)

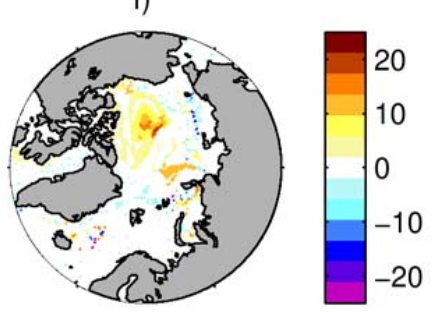

Fig. 8. Time evolution of the modelled characteristics for the Arctic Ocean (treated here as poleward of $\left.66^{\circ} \mathrm{N}\right)$ : (a) extent of the Northern Hemisphere sea ice (September averaged, $\mathrm{km}^{2}$ ); (b) $\Omega_{\mathrm{a}}$ for the control run (black); fast (red) and slow ice decline (blue); high (green) and low (magenta) diffusivity experiments; (c-f): difference in the date (years) of the first occurrence of undersaturated conditions in respect to aragonite between the control run and the following numerical experiments: fast (c), slow (d) ice decline; low (e), high (f) diffusivity. Negative numbers denote earlier undersaturation onset dates than in the control run.

of reduced mixing of fresh surface waters with those of the deeper ocean. Although acceleration of the Beaufort Gyre does not occur in this latter case, it is still an area of maximum salinity decline.

Qualitatively similar changes in undersaturation onset, albeit weaker ones, take place in the Amudsen-Nansen Basin gyre. In both slow ice decline and low-diffusivity experiments this occurs $10-15 \mathrm{yr}$ earlier than in the control run, while in the fast ice decline and high diffusivity experiments undersaturation onset is delayed by $10-12 \mathrm{yr}$.

Another area of strong sensitivity is located within the northern part of the Nordic Seas, in the province identified in the budget analysis of Sect. 3.1 as Nordic minimum (cf. Fig. 5a), and characterised by strong deepening of the winter convection over the 21 st century that acts to buffer the decline in $\Omega_{\mathrm{a}}$ (Sect. 3.1). In the low-mixing and slower ice decline experiments, undersaturation onset is accelerated here by about $20 \mathrm{yr}$ due to delay in deepening of mixing in both cases.

\subsection{The Arctic from a global perspective}

In this section we aim to compare the conditions influencing acidification and saturation state in the Arctic Ocean with those of the rest of the world ocean. One of the most important consequences of global warming for the marine biota and the ocean carbon system is the stabilisation of ocean stratification. This leads to a reduction in the surface concentrations of nutrients available for primary production as well as a stronger separation between surface layers in contact with the atmosphere and intermediate and deep layers which have higher DIC and lower (at the present day) $\Omega$ and $\mathrm{pH}_{\mathrm{SWS}}$ (see Yool et al. (2013b) and references therein). Globally averaged values of the maximum depth of mixing (Fig. 1d) show a shallowing of this depth from 137 to $127 \mathrm{~m}$ by the end of the century, although geographical variations are substantial (Fig. 9a, b). The most pronounced shallowing of the winter mixing occurs in the Pacific and Atlantic sectors of the Southern Ocean and in the northern North Atlantic, as well as in areas of the Atlantic inflow into the Arctic 
Ocean (Fig. 9b). The Arctic Ocean provides a marked exception from the general tendency of the ocean to stratify in response to climate warming. In our projections for the Arctic Ocean, winter mixing deepens with the exception of areas most affected by Atlantic inflow (see details in Sect. 3.1). This deepening of winter mixing tends to buffer the decline in $\mathrm{pH}_{\mathrm{SWS}}$ and $\Omega$ caused by rising atmospheric $\mathrm{CO}_{2}$.

In order to assess effects associated with nutrient regime, we chose to examine the variation in annual maximum of dissolved inorganic nitrogen (DIN). The shallowing of winter mixing leads to a decline in globally averaged maximum surface DIN (Fig. 1c, d) although spatial patterns of its distribution show substantial geographical variation. While the majority of the surface ocean shows a decline of DIN (Fig. 9c, d), one notable exception is the northern North Pacific, where deepening of winter mixing allows access to subsurface waters rich in nutrients. The Arctic Ocean shows a strong decline in maximum DIN and widespread oligotrophic conditions in spite of the deepening of winter mixing, with the exception of areas affected by Pacific inflow, which is characterised by relatively high DIN concentrations. Projected global net primary production shows a consistent decline from 2010 , falling by $6 \%$ across the 21 st century. The regional response of the net primary production, however, shows both positive and negative deviations after year 2000 (Fig. 9e, f). The two most prominent areas in this respect are the North Atlantic and the Arctic Ocean. In the former, the net primary production declines as a result of the shallowing of winter mixing. However, in the case of the latter, net primary production increases over a substantial part of the basin as a result of the improved light regime (caused by sea ice retreat) and higher nutrient supply rates (caused by deepening of winter mixing).

Increasing atmospheric $\mathrm{CO}_{2}$ leads to an increase in surface DIC (Fig. 10a-c), seen most prominently in the central Arctic Ocean. Globally, climate change effects mitigate this increase (Fig. 10c). This is most pronounced in the northern North Atlantic and areas of the Arctic Ocean affected by inflows from the North Atlantic and Pacific. The impact of climate change is more substantial than that of the increase in DIC in these areas due to the equilibration of the surface ocean with increasing atmospheric $\mathrm{CO}_{2}$. The main mitigating factors in areas such as the Arctic Ocean are the shallowing of winter mixing (Fig. 9b) and the increase in the net primary production (Fig. 9f). However, the central Arctic Ocean is a pronounced exception, since here climate change accelerates the increase of surface DIC due to the retreat of sea ice (Sect. 3.1).

Following the increases in atmospheric and oceanic $\mathrm{CO}_{2}$, globally averaged $\mathrm{pH}_{\mathrm{SwS}}$ declines from 8.1 to 7.7 (Fig. 10d-f), this change being nearly homogeneous across the globe. Again, the Arctic Ocean is an exception, and here the basin-averaged $\mathrm{pH}_{S W S}$ decline is largest $(-0.5)$, although there is strong spatial variability in this decline, ranging from -0.3 in the Greenland Sea to -0.6 in the Canada Basin
(Fig. 4d). Climate change has only a small effect on $\mathrm{pH}_{\mathrm{SwS}}$ because of the compensating temperature effect that buffers DIC (e.g. McNeil and Matear, 2007). Once again, the Arctic Ocean is a special case where climate change factors (sea ice retreat and surface freshening) accelerate the decline of $\mathrm{pH}_{\mathrm{SWS}}$, most noticeably in the central basin. While at present the Arctic Ocean is an area that exhibits some of the highest surface $\mathrm{pH}_{\mathrm{SWS}}$ values in the world ocean, it is projected to become an area of the lowest $\mathrm{pH}_{\mathrm{Sws}}$ by the end of the century as a result of climate change (Fig. 10d, e).

$\Omega_{\mathrm{c}}$ and $\Omega_{\mathrm{a}}$ are projected to decline by 2 units globally (Fig. 1i). The decline is higher at low latitudes and lower at high latitudes, especially in the Arctic Ocean (Fig. 10i, 1). On average, climate change mitigates the decrease of $\Omega$, with maximum impact at high latitudes. Projected changes in surface $\Omega$ by the end of the century are much less homogeneous than $\mathrm{pH}_{\mathrm{SWS}}$ although, as for $\mathrm{pH}_{\mathrm{SWS}}$, the decline is maximal in the Arctic Ocean. Unlike $\mathrm{pH}_{\mathrm{SWS}}$, however, climate effects buffer changes in $\Omega$ brought about by the increased atmospheric $\mathrm{CO}_{2}$ in nearly all ocean regions with the exception of most areas of the Arctic. In these latter areas, climate change effects accelerate the decline of $\Omega$ (Fig. 10i, 1).

\section{Discussion}

Due to polar amplification, the effect of climate change is greater at the poles compared to the rest of the globe. This amplification is thought to be largely a result of the retreat of sea ice and associated feedbacks (e.g. Moritz et al., 2002). It is likely to continue in future, with the possibility of a seasonally ice-free Arctic in the 21st century (e.g. Zhang and Walsh, 2006). The ongoing retreat of sea ice additionally brings about substantial changes to the freshwater balance of the region and increases the exposure of the ocean surface to the atmosphere with associated changes in upper ocean stratification and the net primary production. This increase in the spatial extent of open water in the Arctic Ocean also permits the equilibration of ocean and atmospheric $\mathrm{CO}_{2}$ in areas previously covered by perennial ice, with resulting consequences for the associated carbonate chemistry. The Arctic Ocean has shown an early onset of the effects of acidification, characterised by low values of $\mathrm{pH}_{\mathrm{SwS}}$ and carbonate saturation state (Yamamoto-Kawai et al., 2009). Observations already show undersaturated waters in various regions of the Arctic, including the Canada Basin (Yamamoto-Kawai et al., 2009), freshwater-influenced shelves (Chierici and Fransson, 2009) and the Chukchi, Beaufort and eastern East Siberian seas (Bates et al., 2011). A number of future projections for $\mathrm{pH}_{\mathrm{SWS}}$ and $\Omega$ have been made using models that take into account the effects of climate change (Orr et al., 2005; McNeil and Matear, 2007; Steinacher et al., 2009; Yamamoto et al., 2012). These studies have identified temperature, and its buffering effect on $\mathrm{CO}_{2}$ exchange with the atmosphere, as the main climate change factor affecting undersaturation 
a) $U M L_{\max }(2000)$
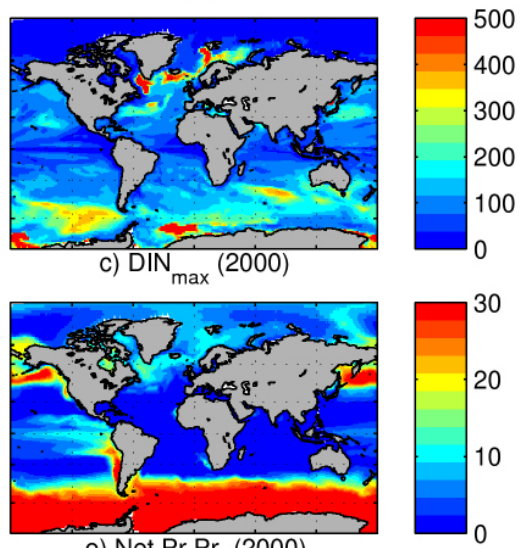

e) Net Pr.Pr. (2000)
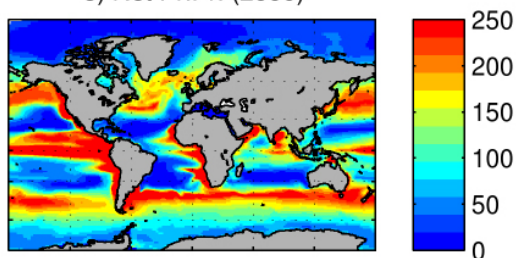

b) $\Delta \mathrm{UML}_{\max }$
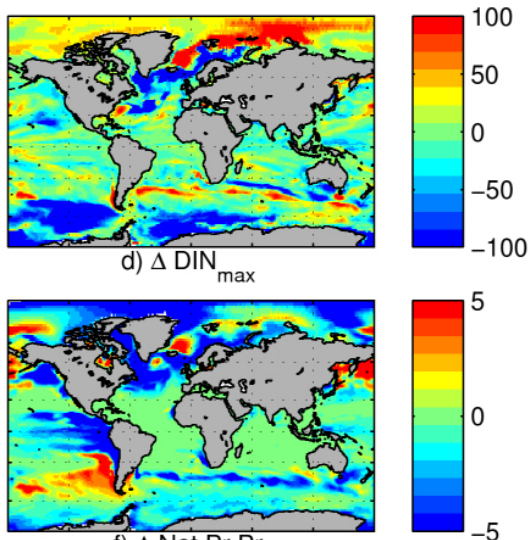

f) $\Delta$ Net Pr.Pr
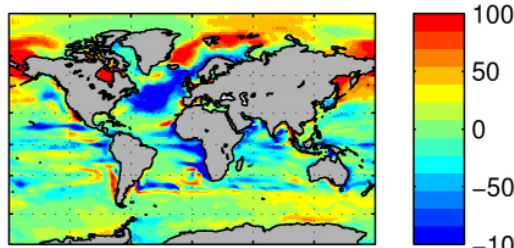

Fig. 9. Global surface maps of the upper mixed layer maximum $(\mathbf{a}, \mathbf{b}$ in $\mathrm{m})$, surface DIN $\left(\mathbf{c}, \mathbf{d}\right.$ in $\left.\mathrm{mmol} \mathrm{m}^{-3}\right)$, net primary production $(\mathbf{e}, \mathbf{f}$ in $\mathrm{g} \mathrm{C} \mathrm{m}^{-2} \mathrm{yr}^{-1}$ ). Values are given for year 2000 (left column) and for deviation between year 2099 and year 2000 (right column).

a) CT (1900)

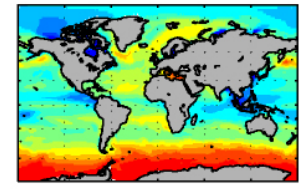

d) $\mathrm{pH}_{\mathrm{sws}}(1900)$

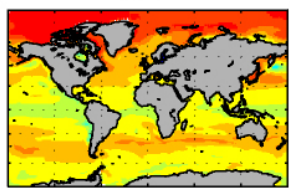

g) $\Omega_{\mathrm{c}}(1900)$

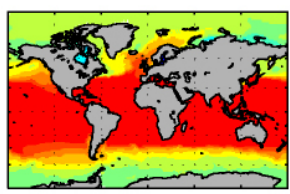

j) $\Omega_{\mathrm{a}}(1900)$

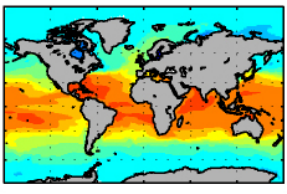

b) $\Delta \mathrm{CT}$ (Full run)

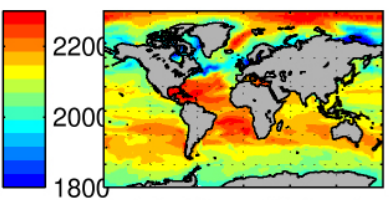

e) $\Delta \mathrm{pH}_{\text {sws }}$ (Full run)
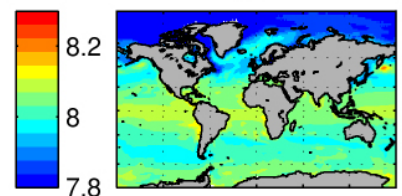

h) $\Delta \Omega_{c}$ (Full run)
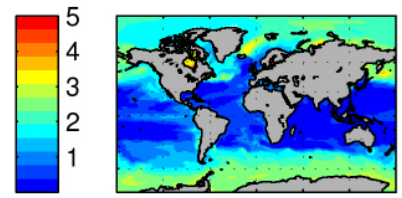

k) $\Delta \Omega$ (Full run)
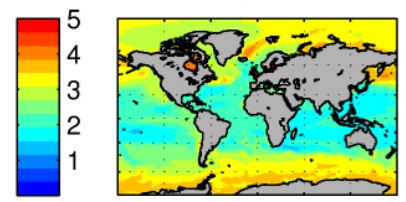

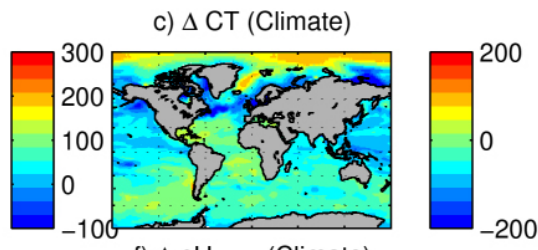

f) $\Delta \mathrm{pH}_{\text {sws }}$ (Climate)
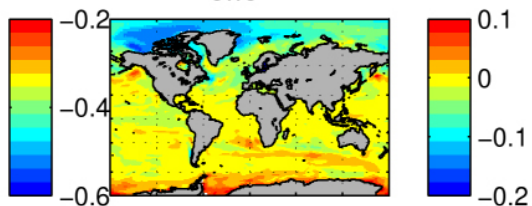

i) $\Delta \Omega_{c}$ (Climate)
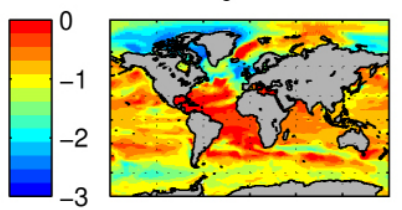

I) $\Delta \Omega_{a}$ (Climate)
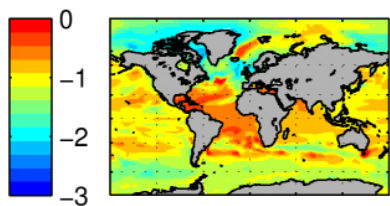

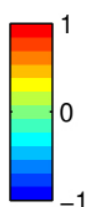

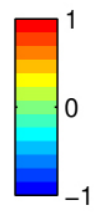

Fig. 10. Global surface maps of DIC $\left(\mathrm{mmolm}^{-3}\right)(\mathbf{a}-\mathbf{c}), \mathrm{pH}_{\mathrm{SWS}}(\mathbf{d}-\mathbf{f}), \Omega_{\mathrm{c}}(\mathbf{g}-\mathbf{h})$ and $\Omega_{\mathrm{a}}(\mathbf{j}-\mathbf{l})$. The first column shows values for year 2000 ; the second column shows deviation between year 2099 and year 2000 for the full run, and the third column shows deviation between year 2099 and year 2000 for the climate change run. 

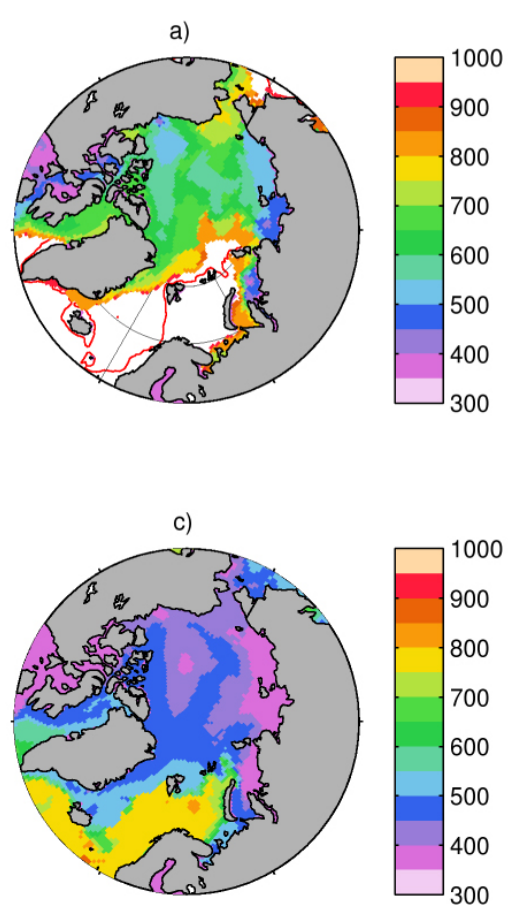

b)

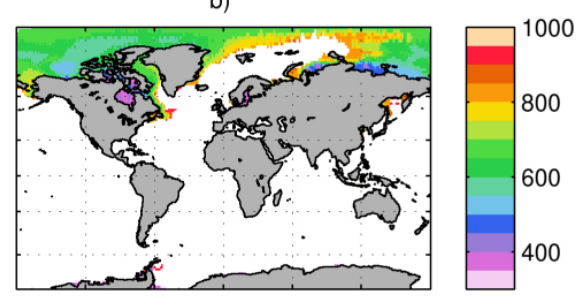

d)

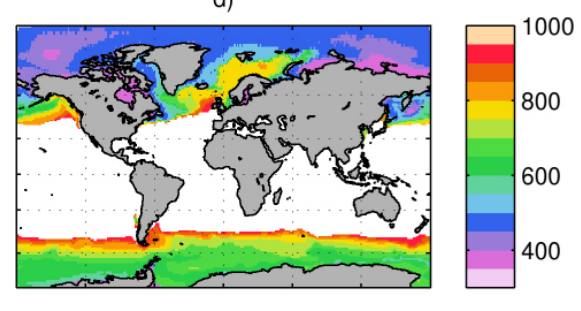

Fig. 11. Level of atmospheric $\mathrm{CO}_{2}(\mathrm{ppm})$ under which monthly mean undersaturated surface waters occur for the fist time in respect to calcite (a, b) and aragonite $(\mathbf{c}, \mathbf{d})$.

with respect to calcite and aragonite in the global ocean. The general consensus obtained in these studies is that climate change effects have little net impact on projected $\mathrm{pH}_{\text {SWS }}$ but that they substantially buffer the decline in $\Omega$ caused by increasing $\mathrm{CO}_{2}$. The Arctic Ocean, however, is a considerably more complex region. Melting sea ice causes $\mathrm{pH}_{\mathrm{SWS}}$ and $\Omega$ to decline markedly (McNeil and Matear, 2007; Yamamoto et al., 2012), both as a result of the relatively low $\mathrm{pH}_{\mathrm{SwS}}$ of melting ice water and because of the greater exposure of previously ice-covered waters to the atmosphere and the consequent ventilation of $\mathrm{CO}_{2}$. Various projections show that the Arctic Ocean will become locally understaurated (in at least one month per year) with respect to aragonite within the current decade (2010-2020) and with respect to calcite during the decade 2040-2050 (McNeil and Matear, 2007; Steinacher et al., 2009; Yamamoto et al., 2012).

Our results are in general agreement with the previous projections described above. They indicate that the Arctic is the first ocean basin to exhibit widespread undersaturation (Fig. 11b, d). We have focused our examination on the strong spatial gradients seen in physical and biogeochemical properties of the Arctic Ocean, which have important consequences for the time evolution of $\mathrm{pH}_{\mathrm{SWS}}$ and carbonate saturation state. The impact of the various climate change drivers on ocean acidification and saturation state in the Arctic is a complex problem to address when making future projections. The various drivers include (i) increase in the temperature of seawater, which directly affects carbonate chemistry and biological production, as well as indirectly affecting the same characteristics via changes in ocean stratification; (ii) changes in the freshwater balance and energy exchange with the atmosphere affecting ocean stratification, which regulate not only the atmospheric exchange of $\mathrm{CO}_{2}$ but also the mixing of deep waters - which are characterised by higher nutrient and lower (at present day) $\mathrm{pH}_{\mathrm{SWS}}$ and $\Omega$ - to the surface; (iii) retreat of sea ice, which accelerates uptake of atmospheric $\mathrm{CO}_{2}$ by the ocean, as well as influencing stratification and providing freshwater inputs that lower $\mathrm{pH}_{\mathrm{SWS}}$ and $\Omega$; and (iv) increase in riverine input, lowering $\mathrm{pH}_{\mathrm{SWS}}$ and $\Omega$ and also stabilising ocean stratification.

The various climate-related factors were projected by our model to operate differently in the various regions of the Arctic Ocean, their role varying from acceleration of acidification rates through to a strong buffering effect. The Canadian Arctic Archipelago, central Arctic and Baffin Bay have the highest inputs of freshwater from melting sea ice which, because of its relative acidity, causes $\mathrm{pH}_{\mathrm{SWS}}$ and $\Omega$ to decline. These regions bear the brunt of the transition towards a seasonally ice-free state as the sea ice retreats, with the result that they experience greater ventilation of $\mathrm{CO}_{2}$ with the atmosphere, which in turn further decreases $\mathrm{pH}_{\mathrm{SwS}}$ and saturation state. The Siberian shelves, in contrast, show slower response to climate change in terms of $\mathrm{pH}_{\mathrm{SwS}}$ and saturation state because increased freshwater input is largely compensated for by elevated rates of net primary production. At the same time the impact of vertical diffusivity and freshwater 
from ice melt - which strongly reduce $\Omega$ in other provinces is nearly negligible. A further variation in climate change impacts is seen in areas affected by the Atlantic inflow, namely the Greenland and Barents seas. In these regions, the deepening of winter mixing associated with diminishing sea ice cover plays a strong role in reducing $\Omega$.

The results from our model indicate that timing of the onset of undersaturation is highly variable across the Arctic, occurring during the decade of 2000-2010 in the Siberian shelves and Canadian Arctic Archipelago, but as late as the 2080s for the Barents and Norwegian seas (corresponding to atmospheric $p \mathrm{CO}_{2}$ of $350-400 \mathrm{ppm}$ and $750-800 \mathrm{ppm}$, respectively: Figs. $6 \mathrm{~b}$ and $11 \mathrm{c}$ ). Note that these projections were made on the basis of a single model and are thus subject to uncertainty associated with this model's internal variability while lacking the reduced uncertainty of ensemble analyses (e.g. Tebaldi and Knutti (2007)). In recent modelling studies, inter-model differences were shown to be particularly pronounced in the Arctic region (e.g. Steinacher et al., 2010; Popova et al., 2012; Steiner et al., 2014; Vancoppenolle et al, 2013), and thus more detailed ensemble-based projections studies focused on the Arctic are needed.

We showed strong sensitivity of our results to the rate of Arctic sea ice decline and strength of vertical mixing. In general, when modelled with faster ice decline or deeper winter mixing, the Arctic Ocean generally shows earlier onset of undersaturated conditions with respect to aragonite, while shallower mixing or slower ice decline delay these conditions. However, the strength of this sensitivity varies strongly across the Arctic Ocean, and is most pronounced in the Beaufort Gyre, an area of substantial freshwater storage. This finding acts as a caution against using regional data sets within the Arctic Ocean for model verifications or attempting to extrapolate localised observations to the pan-Arctic domain. In addition, strong regional variability in the sensitivity of our results warns against the use of basin-wide characteristics in model intercomparison and sensitivity studies.

Arctic rivers are an important source of biogeochemical constituents, including nutrients, dissolved and particulate organic matter. However, the significance of these sources for characteristics of the Arctic Basin as a whole, as well as ways of parameterising them in the ocean biogeochemical models, are still areas of active research (Manizza et al., 2012; Le Fouest et al., 2013). Our study, performed within the framework of an ocean-only model and without a terrestrial component that can provide such fluxes, only crudely parameterises this input, and entirely ignores other aspects such as dissolved organic matter. A detailed sensitivity analysis of the basin-scale Arctic Ocean properties and their future projections to the alternative ways of parameterising riverine input of the biogeochemical properties would be a valuable addition to the debate; however is outside of the scope of this paper and will be addressed in a future study.

The future projections presented herein are based on the RCP8.5 scenario, which ostensibly represents an upper bound of anthropogenic carbon emissions currently under consideration for the upcoming IPCC Fifth Assessment Report. In the event that future levels of $p \mathrm{CO}_{2}$ are higher than values considered in this study, undersaturation will occur even faster than indicated by our model results. The atmospheric $\mathrm{CO}_{2}$ levels that correspond to the onset of aragonite undersaturation, and how this varies spatially within the Arctic Ocean, are shown in Fig. 11. As a first approximation, the $\mathrm{CO}_{2}$ levels shown in this figure may be considered independent of any particular emission scenario. This analysis indicates that widespread Arctic Ocean undersaturation with respect to aragonite occurs before atmospheric $\mathrm{CO}_{2}$ reaches $500 \mathrm{ppm}$. In contrast, the Southern Ocean only begins to experience widespread undersaturation in surface waters when atmospheric $\mathrm{CO}_{2}$ exceeds $550 \mathrm{ppm}$ (year 2050 under RCP8.5). This is higher than the $450 \mathrm{ppm}$ projected by McNeil and Matear (2008) as an atmospheric value under which widespread Southern Ocean undersaturation occurs. Taking into account sensitivity of the undersaturation onset to the rates of vertical mixing demonstrated for the Arctic Ocean, we can assume similar strong sensitivity in the Southern Ocean. We can suggest that only careful model intercomparison study of the underlying physical factors can clarify the underlying reasons for this discrepancy.

We conclude that, in order to make future projections of acidification and carbon saturation state in the Arctic, models of sufficiently high resolution are needed to address regional aspects of physical and biological dynamics. The use of basin-averaged characteristics, while useful for model intercomparison studies, is not optimal for projecting, for example, the timing of the first occurrence of aragonite undersaturation in the Arctic. Forecasting the future progression of ocean acidification in the Arctic Ocean is challenging given the complexity of ocean-atmosphere feedbacks, especially the role of retreating sea ice, as well as being hampered by the paucity of observations available for model verification. A major source of uncertainty in future projections of ocean acidification in the Arctic Ocean is the difference in the sea ice reduction rates projected by climate models (Yamamoto et al., 2012). Our results confirm this conclusion and stress the need for careful model intercomparison studies of Arctic Ocean acidification, with a particular focus on differences in the modelled decline of sea ice.

\section{Conclusions}

- We compared two runs of a global ocean general circulation model that includes biogeochemistry and the carbon cycle, forced by the output from an Earth system model run under RCP8.5 to year 2099. We separated the impacts of rising atmospheric $\mathrm{CO}_{2}$ from associated future climate change and showed that the impact of climate change plays a strong role in driving 
spatial heterogeneity of declines in $\Omega$ and $\mathrm{pH}_{\mathrm{SwS}}$ in the Arctic Ocean.

- Simulation results indicate that the Arctic is the first ocean basin to exhibit widespread surface undersaturation with respect to aragonite and, later, calcite. The onset of surface undersaturation shows great variability between different regions of the Arctic Ocean as a result of differences in climate change feedback factors such as the retreat of sea ice, changes in freshwater input and changes in stratification. The timing of the first occurrence of surface undersaturation with respect to aragonite varies across the Arctic Ocean by nearly a century and shows strong sensitivity to the rates of ice decline and the strength of vertical mixing. Our results thus caution against using coarse-resolution models when modelling future changes in acidification and saturation state in the Arctic.

- In line with previous studies (e.g. Yamamoto et al., 2012), the strongest driving force and the largest uncertainty in projections of Arctic responses to climate change and acidification are the rate of decline of sea ice. Model intercomparison studies that address acidification rates in the Arctic Ocean need to assess such associated processes in relation to model projections of sea ice retreat.

Acknowledgements. The authors acknowledge the financial support of the Natural Environmental Research Council (NERC) within the framework of National Capability and NERC UK Ocean Acidification research programme (Regional Ocean Modelling project). The authors are additionally grateful to the NEMO development team at NOC for their technical support throughout this work. In particular, the assistance of Beverly de Cuevas and Steven Alderson has been invaluable in the development and simulation of MEDUSA-2. The HadGEM2-ES atmospheric forcing was produced by the UKMO and made available for use in NEMO by Dan Bernie (UKMO). Work to perform HadGEM2-ES simulations was supported by the EU-FP7 COMBINE project (grant number 226520). The carbonate chemistry scheme utilised by scMedusa- 2 to calculate, among other things, air-sea $\mathrm{CO}_{2}$ flux was generously supplied by Jerry Blackford (PML). The benthic reservoir scheme used here is based on a similar scheme developed, and supplied, by Momme Butenschon (PML). We are grateful to George Nurser for his help in calculating advective and diffusive fluxes. We would like to acknowledge a substantial role of AOMIP/FAMOS as an excellent forum for exchange of ideas in all aspects of Arctic Ocean modelling and observations.

Edited by: J.-P. Gattuso

\section{References}

Anderson, T. R.: Plankton functional type modelling: running before we can walk?, J. Plankton Res., 27, 1073-1081, doi:10.1093/plankt/fbi076, 2005.

Bates, N. R., Cai, W.-J., and Mathis, J. T.: The ocean carbon cycle in the western Arctic Ocean distributions and airsea fluxes of carbon dioxide, Oceanography, 24, 186-201, doi:10.5670/oceanog.2011.71, 2011.

Bates, N. R., Orchowska, M. I., Garley, R., and Mathis, J. T.: Summertime calcium carbonate undersaturation in shelf waters of the western Arctic Ocean - how biological processes exacerbate the impact of ocean acidification, Biogeosciences, 10, 5281-5309, doi:10.5194/bg-10-5281-2013, 2013.

Carmack, E. and Wassmann, P.: Food webs and physicalbiological coupling on pan-Arctic shelves: Unifying concepts and comprehensive perspectives, Prog. Oceanogr., 71, 446-477, doi:10.1016/j.pocean.2006.10.004, 2006.

Carmack, E., Barber, Christensen, D. J., Macdonald, R., Rudels, B., and E. Sakshaug: Climate variability and physical forcing of the food webs and the carbon budget on panarctic shelves, Prog. Oceanogr., 71, 145-181, doi:10.1016/j.pocean.2006.10.005, 2006.

Chierici, M. and Fransson, A.: Calcium carbonate saturation in the surface water of the Arctic Ocean: undersaturation in freshwater influenced shelves, Biogeosciences, 6, 2421-2431, doi:10.5194/bg-6-2421-2009, 2009.

Collins, W. J., Bellouin, N., Doutriaux-Boucher, M., Gedney, N., Halloran, P., Hinton, T., Hughes, J., Jones, C. D., Joshi, M., Liddicoat, S., Martin, G., O'Connor, F., Rae, J., Senior, C., Sitch, S., Totterdell, I., Wiltshire, A., and Woodward, S.: Development and evaluation of an Earth-System model - HadGEM2, Geosci. Model Dev., 4, 1051-1075, doi:10.5194/gmd-4-10512011, 2011.

Fabry, V. J., Seibel, B. A., Feely, R. A., and Orr, J. C.: Impacts of ocean acidification on marine fauna and ecosystem processes, ICES J. Mar. Sci., 65, 414-432, doi:10.1093/icesjms/fsn048, 2008.

Friedlingstein, P., Houghton, R. A., Marland, G., Hackler, J., Boden, T. A., Conway, T. J., Canadell, J. G., Raupach, M. R., Ciais, P., and Le Quéré, C.: Update on $\mathrm{CO}_{2}$ emissions, Nat. Geosci., 3, 811-812, doi:10.1038/ngeo1022, 2010.

Gangst $\varnothing$, R., Joos, F., and Gehlen, M.: Sensitivity of pelagic calcification to ocean acidification, Biogeosciences, 8, 433-458, doi:10.5194/bg-8-433-2011, 2011.

Gaspar, P., Grégoris, Y., and Lefevre, J.-M.: A simple eddy kinetic energy model for simulations of the oceanic vertical mixing Tests at station papa and long-term upper ocean study site, J. Geophys. Res., 95, 16179-16193, 1990.

Giles, K. A., Laxon, S., Ridout, A. L., Wingham, D. J., and Bacon, S.: Western Arctic Ocean freshwater storage increased by wind driven spin-up of the Beaufort Gyre, Nat. Geosci., 5, 194-197, doi:10.1038/NGEO1379, 2012.

Gruber, N.: Warming up, turning sour, losing breath: ocean biogeochemistry under global change, Philos. T. R. Soc. A, 369, doi:10.1098/rsta.2011.0003, 2011.

Houghton, J. T., Ding, Y., Griggs, D. J., Noguer, M., van der Linden, P. J., Dai, X., Maskell, K., and Johnson, C. A.: Intergovernmental Panel on Climate Change 2001: the scientific basis, Cambridge University Press, Cambridge, UK, 881 pp., 2001. 
Jones, C. D., Hughes, J. K., Bellouin, N., Hardiman, S. C., Jones, G. S., Knight, J., Liddicoat, S., O'Connor, F. M., Andres, R. J., Bell, C., Boo, K.-O., Bozzo, A., Butchart, N., Cadule, P., Corbin, K. D., Doutriaux-Boucher, M., Friedlingstein, P., Gornall, J., Gray, L., Halloran, P. R., Hurtt, G., Ingram, W. J., Lamarque, J.-F., Law, R. M., Meinshausen, M., Osprey, S., Palin, E. J., Parsons Chini, L., Raddatz, T., Sanderson, M. G., Sellar, A. A., Schurer, A., Valdes, P., Wood, N., Woodward, S., Yoshioka, M., and Zerroukat, M.: The HadGEM2-ES implementation of CMIP5 centennial simulations, Geosci. Model Dev., 4, 543-570, doi:10.5194/gmd-4-543-2011, 2011.

Jutterström, S. and Anderson, L. G.: The saturation of calcite and aragonite in the Arctic Ocean, Mar. Chem., 94, 101-110, doi:10.1016/j.marchem.2004.08.010, 2005.

Khatiwala, S., Primeau, F., and Hall, T.: Reconstruction of the history of anthropogenic $\mathrm{CO}_{2}$ concentrations in the ocean, Nature, 462, 346-U110, doi:10.1038/nature08526, 2009.

Le Fouest, V., Babin, M., and Tremblay, J.-É.: The fate of riverine nutrients on Arctic shelves, Biogeosciences, 10, 3661-3677, doi:10.5194/bg-10-3661-2013, 2013.

Madec, G.: NEMO reference manual, ocean dynamic component: NEMO-OPA, Note du Pole de modélisation, Institut Pierre Simon Laplace, Technical Report 27, Note du pôle de modélisation, Institut Pierre Simmon Laplace, France, No. 27, ISSN No. 1288-1619, 2008.

Manizza, M., Follows, M. J., Dutkiewicz, S., Menemenlis, D., McClelland, J. W., Hill, C. N., Peterson, B. J., and Key, R. M.: A model of the Arctic Ocean carbon cycle, J. Geophys. Res., 116, C12020, doi:10.1029/2011JC006998, 2012.

McNeil, B. I. and Matear, R. J.: Climate change feedbacks on future oceanic acidification, Tellus B, 59, 191-198, doi:10.1111/j.16000889.2006.00241.x, 2007.

McNeil, B. I. and Matear, R. J.: Southern Ocean acidification: A tipping point at 450-ppm atmospheric $\mathrm{CO}_{2}$, Proc. Natl. Acad. sci. USA, 105, 18860, doi:10.1073/pnas.0806318105, 2008.

Moritz, R. E., Bitz, C. M., and Steig, E. J.: Dynamics of recent climate change in the Arctic, Science, 297, 1497-1502, doi:10.1126/science.1076522, 2002.

Murray, R. J.: Explicit generation of orthogonal grids for ocean models, J. Comput. Phys., 126, 251-273, 1996.

Orr, J. C., Fabry, V. J., Aumont, O., Bopp, L., Doney, S. C., Feely, R. A., Gnanadesikan, A., Gruber, N., Ishida, A., Joos, F., Key, R. M., Lindsay, K., Maier-Reimer, E., Matear, R., Monfray, P., Mouchet A., Najjar, R. G., Plattner, G. K., Rodgers, K. B., Sabine, C. L., Sarmiento, J. L., Schlitzer, R., Slater, R. D., Totterdell, I. J., Weirig, M. F., Yamanaka, Y., and Yool, A.: Anthropogenic ocean acidification over the twenty-first century and its impact on calcifying organisms, Nature, 437, 681-686, 2005.

Pachauri, R. K. and Reisinger, A.: Contribution of Working Groups I, II and III to the Fourth Assessment Report of the Intergovernmental Panel on Climate Change Core Writing Team, IPCC, Geneva, Switzerland, 104 pp., 2007.

Peters, G. P., Andrew, R. M., Boden, T., Canadell, J. G., Ciais, P., Le Quéré, C., Marland, G., Raupach, M. R., and Wilson, C.: The challenge to keep global warming below $2{ }^{\circ} \mathrm{C}$, Nature Clim. Change, doi:10.1038/nclimate1783, 2012.

Popova, E. E., Yool, A., Coward, A. C., Aksenov, Y. K., Alderson, S. G., de Cuevas, B. A., and Anderson, T. R.: Control of primary production in the Arctic by nutrients and light: insights from a high resolution ocean general circulation model, Biogeosciences, 7, 3569-3591, doi:10.5194/bg-7-3569-2010, 2010.

Popova, E. E., Yool, A., Coward, A. C., Dupont, F., Deal, C., Elliott, S., Hunke, E., Jin, M., Steele, M., and Zhang, J.: What controls primary production in the Arctic Ocean? Results from an intercomparison of five general circulation models with biogeochemistry, J. Geophys. Res.-Oceans, 117, C00D12, doi:10.1029/2011JC007112, 2012.

Popova, E. E., A. Yool, Y. Aksenov, and A. C. Coward, Role of advection in Arctic Ocean lower trophic dynamics: A modeling perspective, J. Geophys. Res. Oceans, 118, 1571-1586, doi:10.1002/jgrc.20126, 2013.

Ridgwell, A., Zondervan, I., Hargreaves, J. C., Bijma, J., and Lenton, T. M.: Assessing the potential long-term increase of oceanic fossil fuel $\mathrm{CO}_{2}$ uptake due to $\mathrm{CO}_{2}$-calcification feedback, Biogeosciences, 4, 481-492, doi:10.5194/bg-4-481-2007, 2007.

Sabine, C. L., Feely, R. A., Gruber, N., Key, R. M., Lee, K. J., Bullister, L., Wanninkhof, R., Wong, C. S., Wallace, D. W. R., Tilbrook, B., Millero, F. J., Peng, T. H., Kozyr, A., Ono, T., and Rios, A. F.: The oceanic sink for anthropogenic $\mathrm{CO}_{2}$, Science, 305, 367-371, doi:10.1126/science.1097403, 2004.

Shine, K. P. and Henderson-Sellers, A.: The sensitivity of a thermodynamic sea ice model to changes in surface albedo parameterization, J. Geophys. Res., 90, 2243-2250, 1985.

Steinacher, M., Joos, F., Frölicher, T. L., Plattner, G.-K., and Doney, S. C.: Imminent ocean acidification in the Arctic projected with the NCAR global coupled carbon cycle-climate model, Biogeosciences, 6, 515-533, doi:10.5194/bg-6-515-2009, 2009.

Steinacher, M., Joos, F., Frölicher, T. L., Bopp, L., Cadule, P., Cocco, V., Doney, S. C., Gehlen, M., Lindsay, K., Moore, J. K., Schneider, B., and Segschneider, J.: Projected 21st century decrease in marine productivity: a multi-model analysis, Biogeosciences, 7, 979-1005, doi:10.5194/bg-7-979-2010, 2010.

Steiner, N. S., Christian, J. R., Six, K. D., Yamamoto, A., Yamamoto-Kawai, M.: Future ocean acidification in the Canada Basin and surrounding Arctic Ocean from CMIP5 earth system models, JGR, in press, 119, doi:10.1002/2013JC009069, 2014.

Stroeve, J., Holland, M. M., Meier, W., Scambos, T., and Serreze, M.: Arctic sea ice decline: Faster than forecast, Geophys. Res. Lett., 34, L09501, doi:10.1029/2007GL029703, 2007.

Tebaldi C. and Knutti, R.: The use of the multimodel ensemble in probabilistic climate projections, Phil Trans. R. Soc. A., 365, 2053-2075, 2007.

Timmermann, R., Goosse, H., Madec, G., Fichefet, T., Ethe, C., and Duliere, V.: On the representation of high latitude processes in the ORCA-LIM global coupled sea ice-ocean model, Ocean Model, 8, 175-201, doi:10.1016/j.ocemod.2003.12.009, 2005.

Vancoppenolle, M., Bopp, L., Madec, G., Dunne, J., Ilyina, T., Halloran, P.R., and Steiner N.: Future Arctic Ocean primary productivity from CMIP5 simulations: Uncertain outcome, but consistent mechanisms, Global Biogeochem. Cy., 27, 605-619, doi:10.1002/gbc.20055, 2013.

Walsh, J. E., Overland, J. E., Groisman, P. Y., and Rudolf, B.: Ongoing climate change in the Arctic, Ambio, 40, 6-16, doi:10.1007/s13280-011-0211-z, 2011.

Yamamoto, A., Kawamiya, M., Ishida, A., Yamanaka, Y., and Watanabe, S.: Impact of rapid sea-ice reduction in the Arctic 
Ocean on the rate of ocean acidification, Biogeosciences, 9, 2365-2375, doi:10.5194/bg-9-2365-2012, 2012.

Yamamoto-Kawai, M., McLaughlin, F. A., Carmack, E. C., Nishino, S., and Shimada, K.: Aragonite undersaturation in the Arctic Ocean: effects of ocean acidification and sea ice melt, Science, 326, 1098-1100, 2009.

Yool, A., Popova, E. E., and Anderson, T. R.: Medusa-1.0: a new intermediate complexity plankton ecosystem model for the global domain, Geosci. Model Dev., 4, 381-417, doi:10.5194/gmd-4381-2011, 2011.

Yool, A., Popova, E. E., and Anderson, T. R.: MEDUSA-2.0: an intermediate complexity biogeochemical model of the marine carbon cycle for climate change and ocean acidification studies, Geosci. Model Dev., 6, 1767-1811, doi:10.5194/gmd-6-17672013, 2013a.
Yool, A., Popova, E. E., Coward, A. C., Bernie, D., and Anderson, T. R.: Climate change and ocean acidification impacts on lower trophic levels and the export of organic carbon to the deep ocean, Biogeosciences, 10, 5831-5854, doi:10.5194/bg-10-5831-2013, $2013 b$.

Zhang, X. and Walsh, J. E.: Toward a seasonally ice-covered Arctic Ocean: Scenarios from the IPCC AR4 model simulations, J. Climate, 19, 1730-1747, doi:10.1175/JCLI3767.1, 2006. 